\section{GOLDEN-CROWNED THRUSH \\ (OVEN BIRD)}

\section{Pearl Sneath, Regina}

Late last spring on a beautiful Sunday afternoon, we had the delightful experience of making the "speaking" acquaintance of a Goldencrowned Thrush. A small heap of gravel which had been piled agains' the fence all winter was newly spread on the drive-way beside the garage. Apparently it contained a most delectable assortment of slugs and bugs of one kind and another. The little thrush suddenly appeared and for about twenty minutes he walked around in the gravel enjoying an unexpected feast. At first we stood motionless, but we soon found that he was so engrossed we could follow him around and he paid not the slightest attention either to us or to the noise of the stream of constantly passing cars on 20th Avenue.

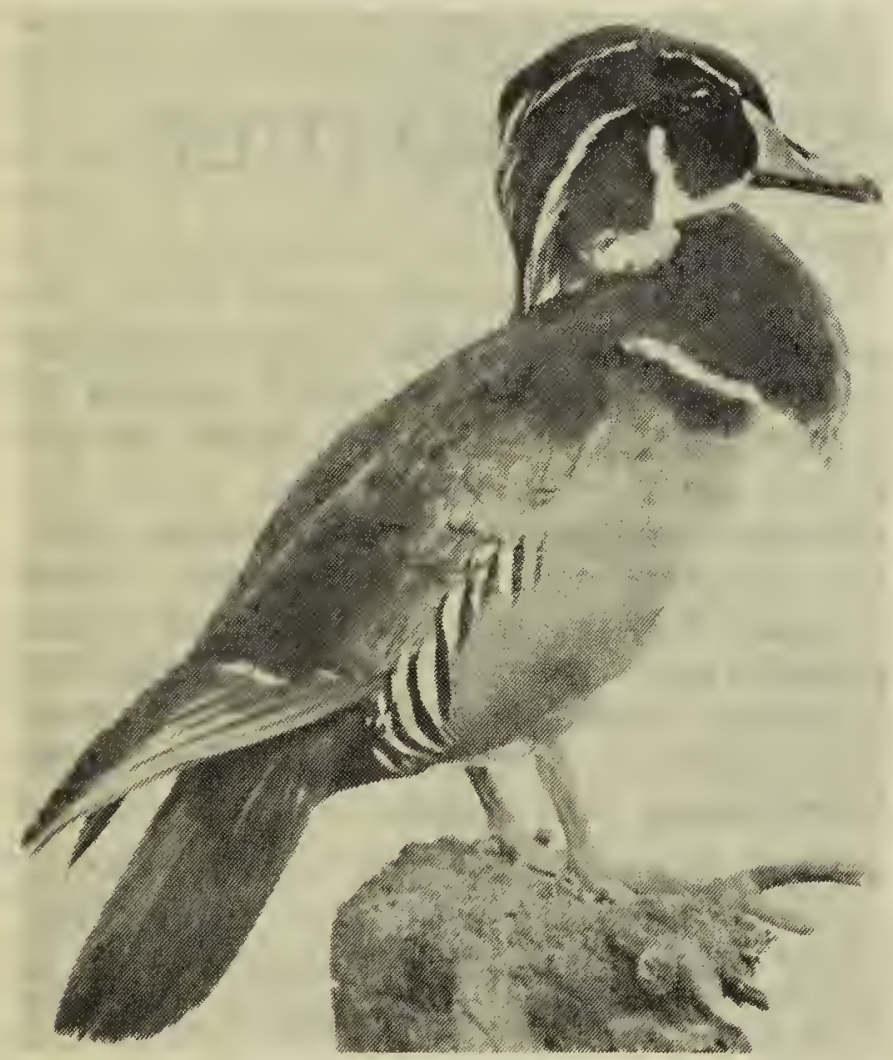

This is the Wood Duck, not to be confused with the Golden-eye. -photo by Fred Bard.
Our previous acquaintance with this most delightful little creature was in the pages of Taverner bird book. Perhaps some readers will advise whether it is a common thing to see one in the heart of the city and close to a busy avenue.

\section{PEEPER}

Mrs. Keith Paton, Oxbow

Two years ago while preparing to burn off a stubble field, my husband found a Mallard's nest with seven eggs in it. Rather than destroy them, we placed them under a setting hen. In due time, three small ducklings hatched, but two got crushed by the hen. The third one, along with several tame ducklings, we placed in a granary for a few days. Our little Mallard friend scorned domestic food and lived solely on flies, which it raced madly after, along the floor.

When they all went to the slough, the wild one stayed with the others and came back to the buildings every night with the rest, when they were called. As soon as it was able to fly it flew up every evening for feed when the rest came. Once in awhile we could catch it, but it never became a real pet. Late in the fall it didn't sleep in the pen with the others but would fly back to the slough after it ate, and wait there for its friends until morning.

Quite often the next summer there was a wild duck with the tame ones as they waddled across the yard. The long journey south had not dimmed "Peeper's" (as we called him) memories of the wheat he ate with his tame friends in our door-yard. Even this year there is a pair of Mallards which seem tamer than most, so maybe he has still escaped the hunters' guns. 